\section{Educational comic: EKSIS CERMIN SI IMUT, as efforts to improve dental and oral health knowledge in Elementary School 12 Kapopposang Island}

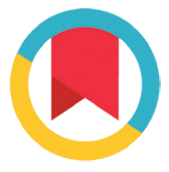

CrossMark

\author{
Ansyari Muis, ${ }^{*}$ Erwin Gunawan, Pharadiba, Febriansyah M. Ashar, \\ Irene E. Rieuwpassa
}

\title{
Abstract
}

Objective: Dental and oral health knowledge is one of the efforts to prevent and cope with dental and oral health problems. The target of this student creativity program is elementary school students in Kapopposang island from third grade to fifth grade.

Material and Methods: The method of implementation of this activity is the presentation of data, preparation of implementation, implementation of activities, evaluation by using pretest-postest and preparing reports.
Results: The average value data pre-test and post-test were analyzed using paired $t$ test with SPSS 24 for Windows. The data shows significant results value $\mathrm{p}(0.000)<0.05$.

Conclusion: The conclusion of this activity can be obtained that the Comic Eksis Cermin Si Imut is effective in increasing students knowledge of class III, IV, and V SDN 12 Kapopposang Island.
Department of Oral Biology, Faculty of Dentistry, Hasanuddin University, Makassar, Indonesia
*Correspondence to: Ansyari Muis, Department of Oral Biology, Faculty of Dentistry, Hasanuddin University, Makassar, Indonesia muisansyari@gmail.com

Received: 15 July 2018 Revised: 31 July 2018 Accepted: 1 March 2020 Available Online: 1 April 2020

Keywords: Comic Dentistry, Education, Knowledge

Cite this Article: Muis A, Gunawan E, Pharadiba, Ashar FM, Rieuwpassa IE. 2020. Educational comic: EKSIS CERMIN SI IMUT, as efforts to improve dental and oral health knowledge in Elementary School 12 Kapopposang Island. Journal of Dentomaxillofacial Science 5(1): 17-21. D0I: 10.15562/jdmfs.v5i1.769

\section{Introduction}

Dental health is often regarded as commonplace for some people. Dental health problems such as cavities and caries are still widely complained by both adults and children. ${ }^{1}$ World Health Organization data (WHO) in 2005 shows that $90 \%$ of the world's children suffer from tooth decay problems. Results of Basic Health Research (Riskesdas) 2007, dental caries suffered by $72.1 \%$ of the population of Indonesia and in the last 12 months as many as $23.4 \%$ of the Indonesian population complained of problems in the teeth and mouth. Of these, only $29.6 \%$ sought help and received treatment from health personnel. This indicates that the still low level of awareness and the level of community utilization of dental services. Still, according to the research, 91.1\% of Indonesians aged over 10 years, despite brushing their teeth every day, only $7.3 \%$ have brushed their teeth correctly, ie morning after breakfast and night before bed. This suggests that most children still do not have the correct behavior in terms of brushing teeth at the right time so as to impact poor oral health. ${ }^{2,3}$

Kapopposang Island is a very difficult area to reach and isolate. Access to Kapopposang Island is taken for 4 hours by boat. Difficult access to Kapopposang Island is also exacerbated by weather conditions, if bad weather conditions then the means of transportation in the form of fishing boats will not be available. This situation caused the people of Kapopposang Island difficult to obtain information including information about oral and dental health. In addition, education is also a major problem faced by Kapopposang Island children. The lack of educational facilities and infrastructure and the lack of motivation to learn the children cause the low level of knowledge of children, especially on oral health issues. Low level of knowledge of children will affect the level of awareness of children about the importance of maintaining healthy teeth and mouth while the age of primary school is a period of growth and development of permanent teeth and teeth mixed so that it will affect the development of dental health in adulthood.

Period 6-12 years is the age of primary school, where the age of 10-12 years is a period of teeth mixed so it takes good action for the maintenance of oral and dental health. ${ }^{2}$ In this period is required more intensive care because at that age there is a change of teeth and the growth of new teeth. ${ }^{4}$ In addition, elementary school-aged children enter into concrete operational stages, where at this time the logical mind of children is still not developed, meaning elementary school students have not been able to think formally. Characteristics, the students 
more easily understand the concept with the help of objects or concrete images so that comics is the right media as an alternative learning of children about dental health as well as a medium of promotion of oral and dental health. ${ }^{5}$

Comics is one of health promotion media in school order. Excess media comics as a media campaign when compared with other media that can increase the desire of the individual as a motivation to learn. The images presented in the comic play a role in stimulating the reader so that they are interested in reading. In addition, comics are more flexible to carry and read over and over. ${ }^{6-8}$ Therefore, through the Eksis Cermin Si Imut program, elementary school students will be counseled and assisted on dental and oral health issues through comic media in order to provide information on how to care for and maintaining healthy teeth and mouth so it is expected to increase the knowledge of students of SDN 12 Kapopposang Island.

\section{Material and Methods}

\section{Presentation of data}

\section{Table 1 Student Data by Level}

\begin{tabular}{llc}
\hline No & Level of students & Numbers of students \\
\hline 1 & Class 3 & 6 \\
2 & Class 4 & 9 \\
3 & Class 5 & 6 \\
& Sum & 21 \\
\hline
\end{tabular}

\section{Preparation of Implementation}

Devotion activities will be implemented after all licenses and equipment preparations have been completed. This devotional activity is done by the method of counseling and direct practice so that it will be different from the teaching and learning activities in general. Extension activities and direct practice will be made as interesting as possible (fun learning).

\section{Preparation of Comic Narratives}

Finding the main problems of child's oral hygiene that most often occur from journals, e-books, text book, and data of Dental Hospital and Mouth Hasanuddin University, record the level of knowledge of dental and oral health of children of SDN 12 Kapopposang Island, prepare narratives or stories by taking into account the available data.

\section{Building Character}

Choosing the main character and character of the comic support by considering the reason or goal to be achieved to be a story of its own. In the development of the concept of character must be able to answer $5 \mathrm{~W}+1 \mathrm{H}$, create a comic character by using Pentab Intvos Comic CTH tool which is a tool to create digital abstract after manual design has been created. In making the character of comic characters there are several procedures performed systematically. The details of the character creation process begins with manual sketches and digital sketches that divide each character individually, create character styles, and shapes and create character-specific attributes.

\section{Making Comics}

Compose the contents of comics in accordance with the narrative and character characters, creating components of comic compiler used in the design, print and duplicate comics.

\section{Activity Implementation}

The devotion activities will be held in the area of Elementary School of 12 Kapopposang Island. In this activity the students will be invited to follow the comic story line so that they seem to be cast in the comic. This will make it easier for children to remember the importance of maintaining healthy teeth and mouth. In the implementation of the students will be tested in advance about the contents of the comic which will then be used as a comparison after counseling with the comic media. This is what will be the benchmark for the success of this creativity program.

\section{Evaluation and Reporting}

\section{Evaluation}

This evaluation aims to see the development of community service programs implemented with a view to know the existing constraints and how to handle it so that the program devotion is done really effective and maximal. This evaluation is in the form of pretest and post test.

\section{Reporting}

Preparation of Initial Reports, preparation of preliminary reports adjusted to the results achieved during the coaching of students of SDN 12 Kapopposang Island, revised Report, report revisions are made in case of errors in initial report generation, preparation of the final report. The final report is made after the revision of the report so that in the preparation of the final report obtained better results.

\section{Data Collection and Analysis}

Data collected in this research is using questionnaire pre test and post test. The recapitulation of this questionnaire consists of the names and results 
of pre test and post test which describes the statement of knowledge about oral health. This questionnaire aims to compare the level of knowledge of SDN 12 Kapoposang Island before and after being given comic as a medium of dental and mouth health education. Answer a questionnaire actually given a score of 1 , while a wrong answer is given a score of 0 . The accumulated percentage of the level of knowledge of children of SDN 12 Kapoposang Island is calculated using the formula:

$$
\begin{aligned}
& \begin{array}{l}
\text { Percentage } \\
\text { of Student } \\
\text { Knowledge }
\end{array}=\frac{\begin{array}{c}
\text { total of the } \\
\text { right answer }
\end{array}}{\text { total question }} \times 100 \%
\end{aligned}
$$

Evidence:

Interpretation of student's level of knowledge:

Good $=$ value $\geq 70 \%$

Medium = value $51-69 \%$

Bad $=$ value $\leq 50 \%$

\section{Results}

The result of this research is followed by 19 students from total 21 students of class III, IV and V SDN

Table 2 Frequency distribution of knowledge level test results of third grade students of SDN 12 Kapoposang Island before and after by comic eksis si imut

\begin{tabular}{lcccc}
\hline Knowledge Level & Pretest & $\%$ & Postest & $\%$ \\
\hline Good & 0 & 0 & 3 & 60 \\
Medium & 4 & 80 & 1 & 20 \\
Bad & 1 & 20 & 1 & 20 \\
Total & 5 & 100 & 5 & 100 \\
\hline
\end{tabular}

Table 3 Frequency distribution of knowledge level test results of fourth grade students of SDN 12 Kapoposang Island before and after being given comic eksis Si Imut

\begin{tabular}{lcccc}
\hline Knowledge Level & Pretest & $\%$ & Postest & $\%$ \\
\hline Good & 5 & 55,56 & 6 & 66,67 \\
Medium & 3 & 33,33 & 3 & 33,33 \\
Bad & 1 & 11,11 & 0 & 0 \\
Total & 9 & 100 & 9 & 100 \\
\hline
\end{tabular}

Table 4 Frequency distribution of knowledge level test results of students of grade V SDN 12 Kapoposang Island before and after being given comic eksis Si Imut

\begin{tabular}{|c|c|c|c|c|}
\hline Knowledge Level & Pretest & $\%$ & Postest & $\%$ \\
\hline Good & 4 & 80 & 4 & 80 \\
\hline Medium & 1 & 20 & 1 & 20 \\
\hline Bad & 0 & 0 & 0 & 0 \\
\hline Total & 5 & 100 & 5 & 100 \\
\hline
\end{tabular}

12 Kapoposang Island. The target student was obtained by using the exhausted sampling method and taken all the students in the class as sample. The statistical analysis used in this study uses a signed rank wilcoxon test that is analogous to paired test for normal ordinal data scales that are not normally distributed which details are in accordance with the data already entered in the data presentation section as follows.

Based on table 2, the data show that $20 \%$ of grade 3 students have not understood the importance of maintaining oral health. However, after being given comic counseling to targeted students, as many as $60 \%$ of students have a good level of knowledge about oral health. That is, there is an increase in third grade students' knowledge after being given counseling with the comic media eksis Si Imut.

Based on table 3, the data shows that $11.11 \%$ of grade 4 students have not understood the importance of maintaining oral health. However, after being given comic counseling to targeted students, the percentage of students with low knowledge level decreased to $0 \%$. In addition, as many as $66.67 \%$ of students have a good level of knowledge about oral health after being given counseling with comic media. That is, there is an increase in knowledge of fourth graders after being given counseling with the comic media eksis Si Imut.

Based on table 4, the data show that no grade $\mathrm{V}$ students have a poor level of knowledge about the importance of maintaining oral health. In addition, there was no increase in the level of knowledge of targeted students after being given extension with the comic media of Eksis Si Imut. That is, the level of knowledge of students before and after being given the Comic Eksis Si Imut did not change.

Based on table 5, the data on the mean values of pre test and post test were analyzed using paired $\mathrm{t}$ test with SPSS for Windows version 24. The data showed significant result $\mathrm{p}$ value $(0.000)<0.05$. Therefore, the data shows a difference between the level of knowledge before and after students given counseling with the comic media eksis Si Imut to third graders, IV and V SDN 12 Kapoposang Island.

\section{Discussion}

Counseling activities with $\mathrm{Si}$ Imut comic media proved effective in increasing the knowledge of students of SDN 12 Kapoposang Island. The data is supported based on the results of research conducted by Zuhriyyatul Haq in 2015. The results showed that the knowledge of respondents after given dental comics increased significantly. ${ }^{1}$ In addition, research conducted by Isrofah mentioned that the more a person receives information the more knowledge. In the study found that the comic 
Table 5 Data on the mean values of pre test and post test being counseled with comics si imut

\begin{tabular}{lccc}
\hline Group & $\begin{array}{c}\text { Pretest } \\
\text { mean } \pm \text { SD }\end{array}$ & $\begin{array}{c}\text { Postest } \\
\text { mean } \pm \text { SD }\end{array}$ & P \\
\hline Class III & $15.20 \pm 4.21$ & $18.40 \pm 4.62$ & $0.042^{\star *}$ \\
Class IV & $18.78 \pm 3.49$ & $21.00 \pm 3.39$ & $0.056^{\star}$ \\
Class V & $20.20 \pm 3.11$ & $21.60 \pm 2.51$ & $0.108^{\star}$ \\
Total & $18.21 \pm 3.91$ & $20.47 \pm 3.60$ & $0.000^{\star}$ \\
\hline
\end{tabular}

${ }^{*} \mathrm{p}<0.05$

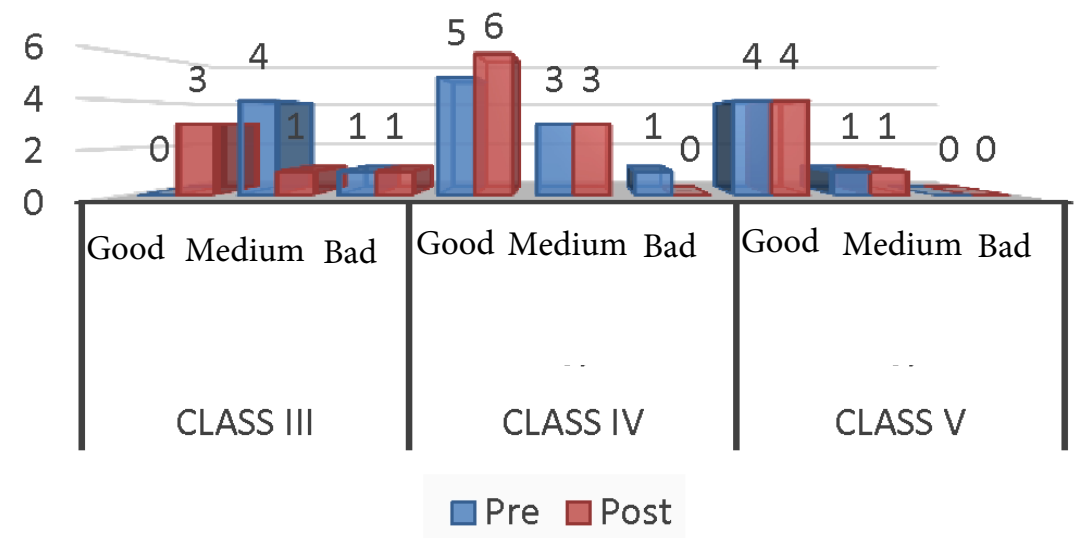

Figure 1 Diagram of the level of knowledge of students of class III, IV, and V SDN 12 Kapoposang Island before and after being counseled with comics si imut

contains a message about treatment and dental health information sodental comics given to the respondents were the driving factors of increasing dental health information received by the respondents. ${ }^{9}$

There are several factors that can affect the high of one's knowledge. One of them based on the characteristics of respondents. Characteristics of respondents by age can affect the knowledge of respondents, especially about dental health. Knowledge is the result of sensing a person towards a particular object through his or her senses. Knowledge will be maximal when influenced by the intensity of attention and perception of a person against a particular object. When reading the comic, the respondent experiences sensing with the five senses. Sensing the images and illustrations on the comics will stimulate the stimulus to recall the messages contained in the comics so that respondents are more interested in reading over and over and there is an increasing knowledge of respondents about dental health. ${ }^{10}$

The book of "Comics Indonesia" explain opinion from Marcel Bonneff that comics as a medium for learning and delivering health messages. Comics as a medium of learning can help respondents in understanding the message because the comic not only contains the text but also images or illustrations. Pictures and illustrations in comics especially health comics can help develop the thinking power of their readers. In addition, the images in the comics stimulate readers to read the comics repeatedly. This allows respondents to understand the message optimally so that in accordance with the research results that the knowledge of respondents increases after being given comic on dental health. ${ }^{11}$

The dental comics given to the respondents have not been able to optimally increase the respondents' trust. This is because the dental comics given are not yet thoroughly convey basic dental health information. Information on dental care summarized in comics can provide more knowledge to respondents. However, the message in the comic has not been thoroughly discussed dental health problems in accordance with existing dental problems. Common dental health problems such as cavities, dental caries and dental treatment are not yet described in detail in the given comics. Dental hygiene concerning proper brushing and dental caries steps is not yet included in the content of comic messages. So it allows the respondent's confidence in the result that dental comics provided have a positive impact in relation to dental health. ${ }^{1}$

\section{Conclusion}

Comis Eksis Cermin Si Imut is effective in increasing the knowledge of third grade students, IV, and V SDN 12 Kapopposang Island concerning oral and dental health.

\section{Acknowledgment}

Thank you to the vice dean for student affairs and alumni of dentistry faculty. Dr. drg. Nurlindah Hamrun, M. Kes, thank you to the lecturer of team, Dr. drg. Irene E. Rieuwpassa, M.Si, thank you to the team lecturer of UNHAS who always give instructions to our team, drg. Nursyamsi, M.Kes, thank you to our friends who are always encouraging to our team and participate in student creativity program activities 2018.

\section{Conflict of Interest}

The authors report no conflict of interest.

\section{References}

1. Haq Z. Penggunaan komik kesehatan gigi dalam mening- katkan pengetahuan dan kepercayaan siswa kelas V SDN Martopuro 01 Kecamatan Purwosari Kabupaten Pasuruan Tahun 2015. J Promkes 2015;3: 124, 126. 
2. Sutjipto C, Wowor VNS, Kaunang WPJ. Gambaran tindakan pemeliharaan kesehatan gigi dan mulut anak usia 10-12 tahun di SD Kristen Eben Haezar 02 Manado. J e-Biomedik (eBM) 2013;1: 698.

3. Pratiwi R, Mutmainnah R. Gambaran keparahan karies pada anak usia 6,9 dan 12 tahun di Kabupaten Pinrang,Sulawesi SelatanmenggunakanindeksPUFA/pufa. Overview of severity of dental caries on 6, 9, and 12 years old children in Pinrang Regency, South Sulawesi using PUFA/pufa index. J Dentomaxillofac Sci 2013;12: 76-77.

4. Namora L, Bahar A, Andreas P. Status keparahan karies gigi pada murid sekolah dasar di daerah tertinggal dan daerah perkotaan. FKG UI 2013: 2-3.

5. Ramlah. Penerapan teori perkembangan mental piaget tahap operasional konkret pada hukum kekekalan materi. Jurnal Pendidikan Unsika 2015:3: 218, 222.

6. Saputro AD. Aplikasi komik sebagai media pembelajaran. Muaddib 2015;5: 2.

7. Ambaryani, Airlanda GS. Pengembangan media komik untuk efektifitas dan meningkatkan hasil belajar kognitif materi perubahan lingkungan fisik. J Pendidikan Surya Edukasi 2017;3: 20-21.
8. Silva AB, Santos GT, Bispo ACK. The Comics as teaching strategy in learning of students in an undergraduate management program. Mackenzie 2017;18: 52-53.

9. Isrofah, Eka N. Pengaruh Pendidikan Kesehatan Gigi Terhadap Pengetahuan dan Sikap Anak Usia Sekolah di SD Boto Kembang Kulonprogo Yogyakarta. Pena Medika Ilmu Kesehatan 2010;1: 5.

10. Husna AR, Reliani. Peningkatan hygiene personal pada anak jalanan dengan media komik di UPTD Kampung Anak Negeri Liponsos Kecamatan Medoan Ayu Rungkut Surabaya. The Indonesian J Health Sci 2016;6: 166.

11. Bonneff M, Hidayat RS. Komik Indonesia. Jakarta: Gramedia; 2008. p. 80.

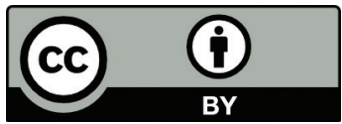

This work is licensed under a Creative Commons Attribution 